\title{
The Mother Tongue and the Foreign Language Correlation in the Primary School in Croatia
}

\author{
Emina Berbic Kolar*, Tanja Duric \\ Faculty of Educational Sciences in Osijek, University of Josip Juraj Strossmayer in Osijek, Croatia
}

Copyright (C) 2016 by authors, all rights reserved. Authors agree that this article remains permanently open access under the terms of the Creative Commons Attribution License 4.0 International License

\begin{abstract}
The paper provides an account of the research on the acquisition of English as the first foreign language and Croatian as the mother tongue among young learners in Croatia. Children become polyglot at the earliest age; they start going to school by speaking their home idiom, and then they learn standard Croatian and the foreign language. English and Croatian, belonging to different language groups, feature different linguistic features, but they still have mutual aspects that can enhance language learning. This hypothesis is examined in the research by observing English and Croatian classes and school success. There are external and internal factors that influence language acquisition, in the paper pupils' attitudes towards language learning are emphasized. The hypothesis is that pupils who are positively oriented towards language learning are more successful when acquiring the language. Research results show that acquisition of both English and Croatian at young age is more or less equally successful, while it decreases in higher grades. It has been indicated that the positive attitude toward language learning can affect successful language acquisition. Therefore it is important to constantly research ways to improve language competence and performance. The school as an important factor has a major role in it.
\end{abstract}

Keywords Mother Tongue, Foreign Language, Croatian, English, Younger Pupils

\section{Introduction}

Multilingualism, as an important feature of the modern society, is defined as an individual ability to use more than two languages in communication. It starts to develop in early age, first as the vertical multilingualism, which refers to learning idioms of the mother tongue (L1). Moreover, if acquiring the foreign language (L2), that is English, takes place at the same time, then it is called horizontal multilingualism (Franić, 2006, 20) [1]. The foreign language is the language that is learnt at schools in the country where it is not official. It is learnt in an unnatural context, the ones who learn it often do not have the opportunity to use it on various occasions. This kind of multilingualism perception is important in order to understand the foreign language reception process and relation between the mother tongue and the foreign language in school environment. The paper deals with the reception of English as the foreign language that is learnt in Croatian schools and Croatian as the mother tongue in lower grades of the primary school. In Croatia, students start learning the foreign language in preschool and they continue to learn it through the primary school, as the obligatory subject. English is most spread foreign language that is learnt in schools, and German is the second most spread in Croatian schools.

Some early findings according to Brown claim that there is an interaction between the mother tongue and the foreign language and that the mother tongue language competence encourages learning the foreign language (Brown, 2000, 208) [2]. Contemporary research conducted within the ELLiE project (2007-2011) and professor Mihaljević Djigunović research (2011) point to inter-linguistic connection between competences at listening, reading and writing levels in the mother tongue and the foreign language (Mihaljević Djigunović, 2011, 269) [3]. This research made significant results important for acquiring the foreign language and interaction between two languages, but still there are not sufficient data about their mutual relation in the class. Therefore, the paper is written in effort to enlighten the relation between the mother tongue and the foreign language learning in the primary school.

Croatian and English belong to the Indo-European language family, Croatian belongs to the Satem language branch and South Slavic languages, and English belongs to the Centum language branch and West Germanic languages. Croatian orthography is phonological - morphological and English is etymological. Most of the words in English are differently written and spelled, which represent the major obstacle in learning English. English morphology is in many aspects easier than Croatian. There are almost the same word classes in both languages, although there are some that exist in English only, such as articles. According 
to Matasović [4], word order in Croatian and English is similar: the subject, the predicate and the object. Therefore, Croatian may contribute to some parts of learning English as the foreign language, but it is important to obey the language rules. Moreover, in the English class, the mother tongue may serve for translating teacher's guidelines in the class and better understanding. However, according to Chomsky [5] it is not highly recommendable to overuse the mother tongue in the foreign language class, otherwise students can get deprived from the foreign language exposure.

On one hand, Croatian language class is organized in five teaching areas: the initial reading and writing (only in the first grade), the language, the language expression, literature and media. Students in lower grades of the primary school attend one Croatian lesson every day. On the other hand, English language class organization follows four basic language skills: listening, speaking, reading and writing. Students in lower grades have the English lesson twice a week (Teaching plan and program, 2006, 12) [6]. Early English language learning has its grounds in listening, miming, dancing, speaking and singing. When learning the foreign language, children often refer to already learnt language rules in the mother tongue and use the mother tongue learning strategies in order to understand foreign language sentences better. Children between seven and eleven learn best by speaking, listening, watching, imitating; they are curious, like to play and fantasize, they also like to do the same mistakes repeatedly, they have short attention span, therefore they need different activities.

Enever lists factors that influence the language learning and acquiring. These are internal or personal: student's personality and individual characteristics (self-esteem, risk taking, language anxiety, empathy, motivation) and external or sociocultural factors that are in student's environment: the teacher, school environment, exposure to the language outside the school, parents education and assistance in learning, school equipment, class atmosphere and discipline, etc. In the paper, students' attitudes towards language learning are emphasized and discussed as one of the most important factors, and the way they reflect their accomplishment in languages (Enever, 2011, 103) [7].

\section{Objectives}

The paper reflects at students accomplishments in English and Croatian and compares them at different age levels (7-11) in the primary school in Croatia. It also encompasses students' attitudes and opinions about Croatian and English. Therefore, main objectives are to correlate accomplishments in two languages and research if they are similar or not at levels mentioned. Another objective is to examine students' emotions and opinions about two languages and compare them together. Therefore, the main objective of the research is to examine the reception of Croatian as the mother tongue and English as the foreign language in the primary school, in lower grades (Year 1 to 4) according to students' grades in these subjects and their attitude towards learning them. The reception refers to the language acquiring as the abstract system of the human mind. Another aspect of the language realization is the language production. The language can be used both for the production and the reception, only if the language knowledge exists, according to Jelaska [8]. In the research, the emphasis is on the language reception, and therefore the language knowledge as well. The research problem is to examine the correlation between the academic success in the mother tongue and the foreign language, what impacts learning and whether positive attitudes towards language learning are connected with higher level of the language knowledge. Hypotheses that are considered in the research are:

H1: Croatian and English parallel learning does not decrease language acquiring in lower grades of the primary school, but enhances intercultural knowledge.

$\mathrm{H} 2$ : Students are more successful in the mother tongue learning (Croatian).

H3: Positive attitude towards language learning implies greater success in the language learning.

\section{Materials and Methods}

\subsection{Research Duration and Sample}

The research was conducted from 17th March 2014 to 4th April 2014. The convenience sample of respondents was used that was in close researchers' environment. In the research, students of lower grades of one rural primary school in Brod-Posavina county participated. For each grade, two classes participated. The sample of respondents consists of 125 students, including 62 girls and 63 boys. In the first grade participated 30 students, in the second grade 32 students, in the third grade 34 students and in the fourth grade 29 students. Moreover, eight classroom teachers, two English teachers and the headmaster participated in the research.

\subsection{Research Methods}

Quantitative and qualitative research methods were used in the research. Among qualitative methods are semi-structured interviews with classroom and English teachers, the headmaster and focus groups. Among quantitative methods students' school grades analysis in Croatian and English is used, and surveys for students in order to estimate students attitude towards language learning (Milas, 2009, 47) [9].

The survey was conducted during the Croatian lesson and was preceded by researchers' guidelines. The survey was specially designed for the first grade and did not consist of questions, but statements because students still did not know how to read and write properly. Therefore, emoticons 
were used as answers, students had to circle one in each statement. Statements were read to students by researchers. They were written in a manner that corresponds to the question content for other classes. Questions in the rest of the surveys varied: multiple-choice questions, ranking questions, open-ended questions. Both types of survey consisted of ten questions. The first part of questions in the survey was about Croatian, and the second one about English (How much do you like learning Croatian/English? How easy is Croatian/English for you? What is the most interesting thing to do in Croatian/English class for you? Rank activities in the Croatian/English class according to preference, from the most likeable to the least likeable: drawing, writing, talking, acting, listening, singing.) The second, the third and the fourth grades had an additional question, whether Croatian helps them to understand English better and how.

In addition, arithmetic means of school grades in Croatian and English at the end of the first school semester were gathered, and those of the second, the third and the fourth grade. In the first grade, there are no numerical grades at the end of the first school semester, only descriptive ones, so these students were not included in data processing. Final grades in Croatian and English of the fourth grade were collected retrospectively in order to get an insight into their language success development during four years in the school.

Moreover, classroom and English teachers provided their insights in Croatian and English classes in interviews, as well as their insight in students' success in each language. In the end, the headmaster gave her insight about school conditions (modern technology, international cooperation, celebrating events connected with languages, etc.) Interviews were taped.

\subsection{Data Processing}

While analyzing the results, as data processing methods, arithmetic means of school grades were used (AM), maximum (MAX) and minimum (MIN) of school grades. The data are presented in percentages and descriptive.

\subsection{Focus Groups}

Four focus groups were gathered, for each class one, where number of students for each class was equally represented, 39 student in total. Students in focus groups talked with the researchers about their attitudes towards Croatian and English learning. Questions for students were similar to those in the survey.

\section{Results}

School grades analysis at the end of the first semester for the second, the third and the fourth grade shows that students are more successful in English than in Croatian, while in the fourth grade it is the opposite. The level of success in English gradually decreases during three years of schooling, while success in Croatian varies: a slight decrease in success in the third grade is registered, while in the fourth grade success increases, as in the second grade. The minimum grade in English in three years of schooling is satisfactory, and in Croatian is good, while maximum grade in both subjects is excellent (Table 1 and 2.)

Table 1. Arithmetic means of school grades in Croatian and English through classes

\begin{tabular}{|c|c|c|c|}
\hline Class & N & AM - CRO & AM - ENG \\
\hline 2 & 33 & 4,03 & 4,5 \\
\hline 3 & 34 & 3,88 & 4,15 \\
\hline 4 & 29 & 4,03 & 3,62 \\
\hline
\end{tabular}

Table 2. Maximum and minimum of school grades through classes

\begin{tabular}{|c|c|c|c|c|}
\hline \multirow{2}{*}{ Class } & \multicolumn{2}{|c|}{ CRO } & \multicolumn{2}{c|}{ ENG } \\
\cline { 2 - 5 } & MIN & MAX & MIN & MAX \\
\hline 2 & 3 & 5 & 3 & 5 \\
\hline 3 & 3 & 5 & 2 & 5 \\
\hline 4 & 3 & 5 & 2 & 5 \\
\hline
\end{tabular}

The success line in Croatian and English in 2013/14 shows that the level of success in English decreases during years, but the level of success in Croatian varies (Figure 1). Total students' success in English is greater than in Croatian, which can be seen according to the arithmetic means of school grades, although the difference is insignificant (AM $(\mathrm{CRO})=3,98, \mathrm{AM}(\mathrm{ENG})=4,09)$.

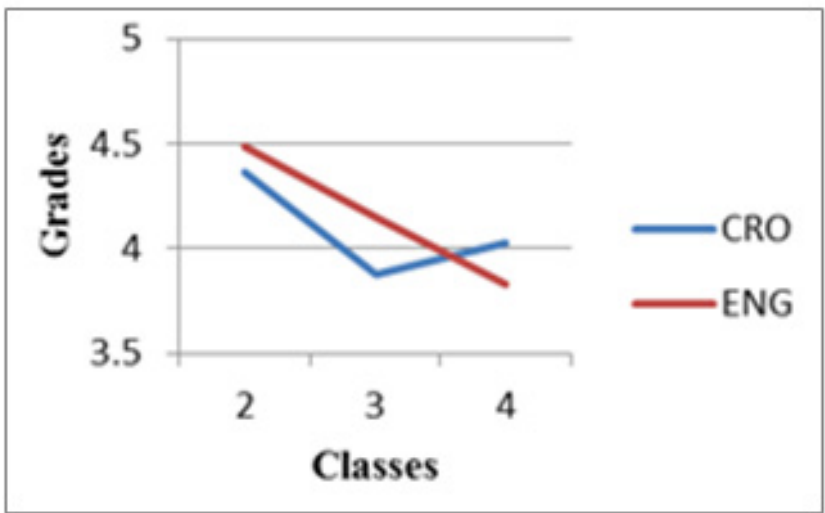

Figure 1. Students' success in Croatian and English (2013/14)

While conducting the research about the level of success of the fourth graders in English and Croatian during four years of their schooling, their final grades at the end of the first, the second and the third grade were taken into consideration, as well as arithmetic means in Croatian and English at the end of the first semester of the fourth grade. Arithmetic means of students' grades in Croatian and English at the end of each school year show that the success 
in Croatian and English gradually decreases through years, while the fall is more stressed in English, which can be seen from the success curve (Table 3 and Figure 2). However, the success of the fourth grade through four years of schooling is greater in English $(\mathrm{AM}=4,32)$, than in Croatian $(\mathrm{AM}=4,22)$.

Table 3. Fourth graders success (2010-2014)

\begin{tabular}{|c|c|c|c|c|}
\hline Subject $(\mathrm{AM})$ & $1^{\text {st }}$ grade & $2^{\text {nd }}$ grade & $3^{\text {rd }}$ grade & $4^{\text {th }}$ grade \\
\hline CRO $(\mathrm{AM})$ & 4,48 & 4,28 & 4,1 & 4,03 \\
\hline ENG $(\mathrm{AM})$ & 4,31 & 4,72 & 4,66 & 3,62 \\
\hline
\end{tabular}

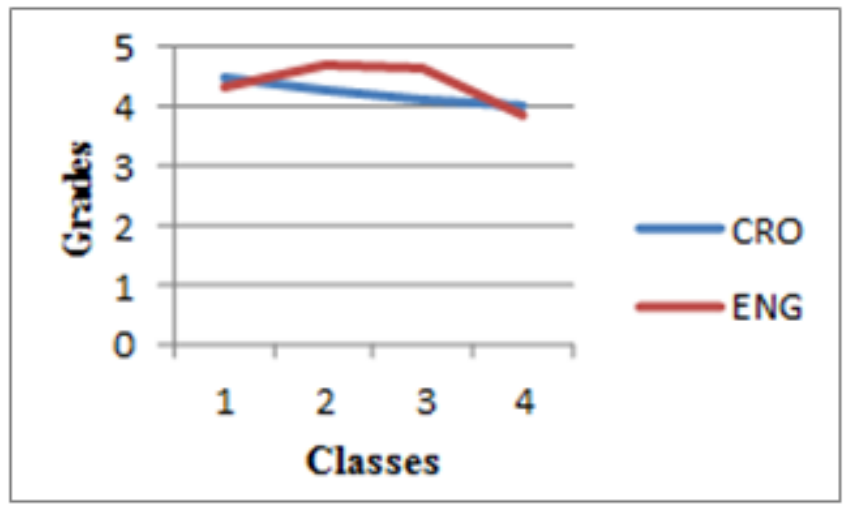

Figure 2. Arithmetic means in Croatian and English of the fourth graders (2010-2014)

Survey results in the first grade show that majority of students like learning English very much (97\%) and Croatian (90\%). English has the slight advantage over Croatian. Students like activities in Croatian evenly: reading $(90 \%)$, writing and drawing $(87 \%)$, and talking $(93 \%)$. The case is the same with English: $93 \%$ like reading very much, $100 \%$ like writing and drawing, and $97 \%$ like talking very much. $43 \%$ of students think Croatian is a bit hard, $43 \%$ think it is so-so hard and $13 \%$ think it is very hard to learn. 90\% think that English is a bit hard, 3\% so-so and 7\% very hard, which indicate that Croatian is harder to acquire in the first grade.

The survey for the second, the third and the fourth grade was the same, so the results were processed together. The sample consisted of 96 students from the second to the fourth grade. The survey consisted of ten questions. Five questions were multiple choice type, three questions were open-ended type and two last questions were the ranking type.

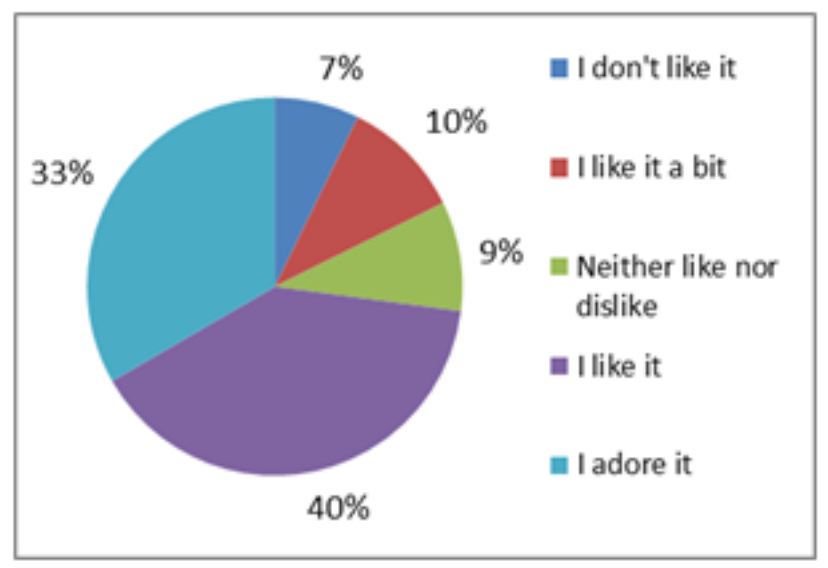

Figure 3. How much do you like learning Croatian?

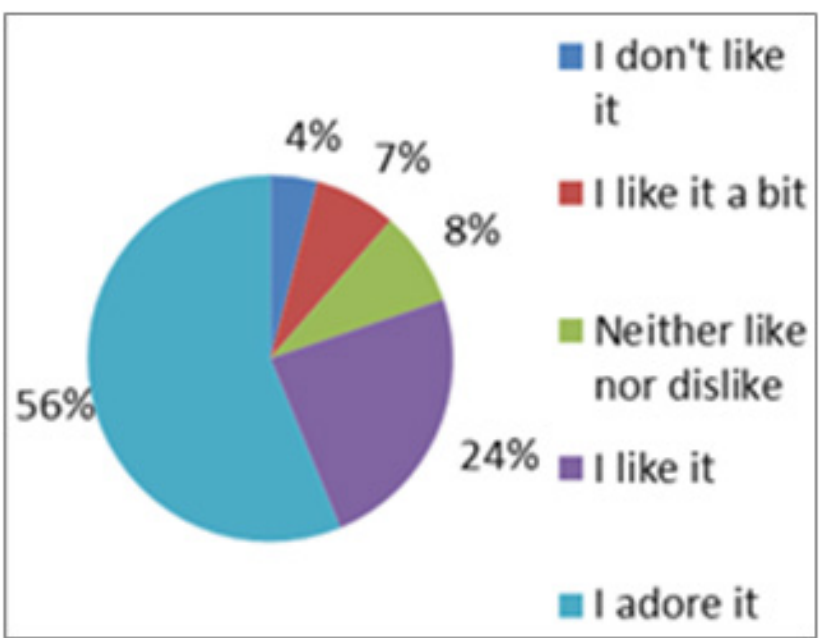

Figure 4. How much do you like learning English?

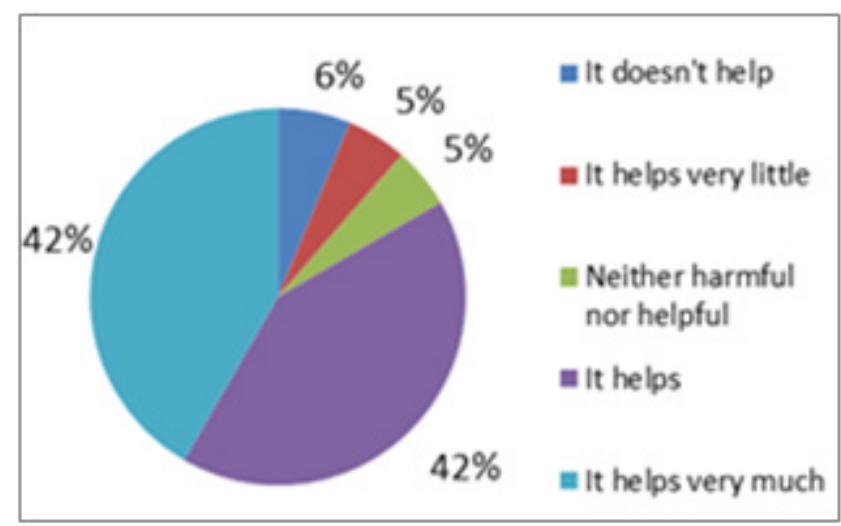

Figure 5. Does Croatian help you in learning English? 


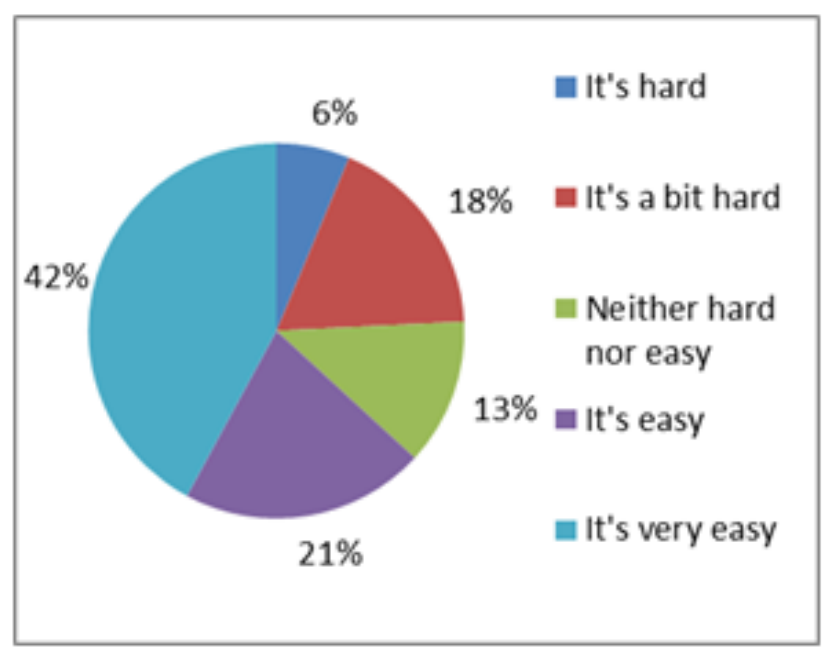

Figure 6. How hard is learning Croatian for you?

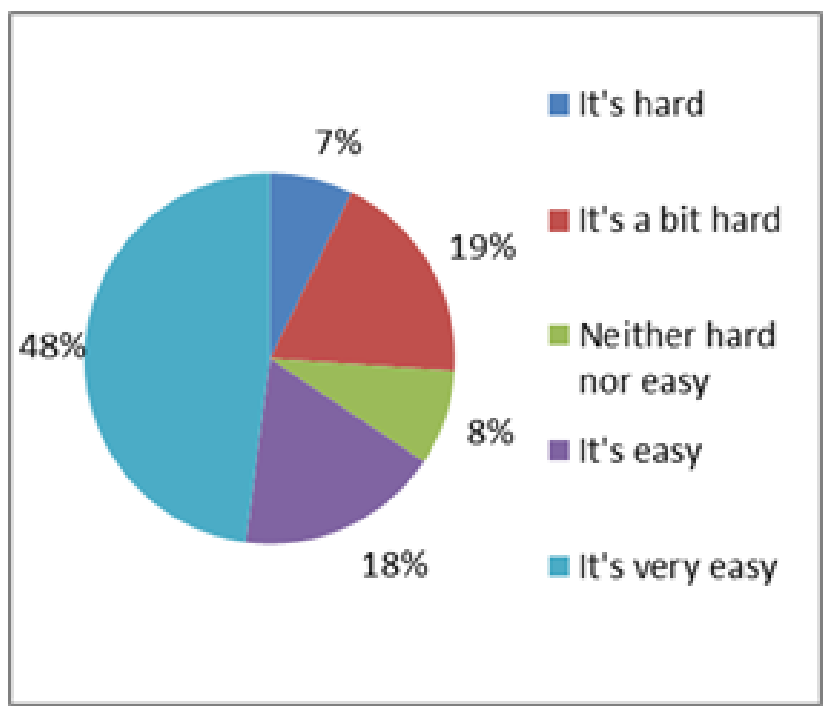

Figure 7. How hard is learning English for you?

Table 4. Activities according to students' preferences

\begin{tabular}{|c|c|}
\hline Croatian & English \\
\hline Reading & Singing \\
\hline Writing & Reading \\
\hline Listening & Talking \\
\hline Talking & Listening \\
\hline Acting & Acting \\
\hline & Writing \\
\hline
\end{tabular}

According to the results, the greater percentage of respondents said that they like learning Croatian and English, while smaller percentage do not like or like a bit learning Croatian and English (Figures 3 and 4). Greater percentage think that Croatian can enhance English learning, while smaller percentage think that Croatian does not help them or helps a bit in better understanding of English (Figure 5). Greater percentage of students think that Croatian and English are very easy to learn, but very little respondents think that Croatian and English are hard to learn. (Figures 6 and 7).
Students provided answers to the open-ended question: how can Croatian help them in acquiring English. These were some common answers: When the teacher translates something in Croatian./ It helps me to understand what the teacher says./ It helps me to remember things better./ Because some words are pronounced the same as in Croatian. It helps me because we do a lot of similar things in Croatian and English. It helps me to understand what is happening in English and how.

In the open-ended question What do you like to do in Croatian?, students provided answers: writing descriptions and poems $(52 \%)$, reading $(47 \%)$ and obligatory reading (23\%). Furthermore, acting (21\%), drawing (18\%), learning new things $(17 \%)$, talking and discussing (12\%), doing tasks in the workbook $(10 \%)$, reciting and learning songs by heart $(8 \%)$, games $(6 \%)$, watching movies $(4 \%)$, writing tests $(4 \%)$, listening $(2,4 \%)$, group work $(2,4 \%)$, singing $(2,4 \%)$, making posters $(1,6 \%)$, writing homework $(1,6 \%)$.

Activities that students listed as the most interesting in the English class are: singing (36\%), reading (34\%), games $(32 \%)$, learning new things and words $(28 \%)$, writing $(23 \%)$, drawing (15\%), talking $(10 \%)$, listening (10\%), writing tests $(7 \%)$, coloring $(4 \%)$, doing tasks $(4 \%)$, doing tasks in the workbook $(3 \%)$, acting (3\%) and group work (1\%). Most students ranked activities in Croatian in the following order according to the preferences, starting from the most likeable to the least likeable activity in the class: reading, writing, listening, acting and talking. Most of the students ranked activities in English in this way: singing, reading, talking, listening, acting and writing (Table 4). Students ranked reading on the first and the second place in Croatian and English, listening and talking are in the middle. However, talking is more valued in English, while acting is in the end of the list in both languages. The difference in the choice of activities is that students like to write more in Croatian than in English. That is possible because words in English are written and pronounced differently, whereas writing in Croatian is more of a creative nature. Therefore, students can express their skills, such as writing poems and stories.

The interview with classroom teachers confirms that students are positively oriented towards the Croatian class and the teaching content. Teachers emphasize that students are more interested in literature and language expression than in the language itself. They are interested in creative work, such as narrating and text reading, doll making, games, crosswords, while they are less interested in language contents and obligatory reading.

Students in the second, the third and the fourth grade have supplementary classes for weaker students and additional classes for talented students. Students also have a drama group as an extracurricular activity where they can develop their literary and acting skills. Some classes submit written works for different writing contests for children. Teachers say that they rarely conduct Croatian and English class correlation, but that it is possible to achieve it in some parts of the lesson (i.e. colors, technology terms, family members, etc.) 
The English teachers say that students' attitude towards English in the early age is extremely positive and that students are very active and interested in the language class. Also, students of that age have great language self-confidence, they are not afraid to make mistakes when speaking, they accept correction. They do not fear of the language. However, at the end of the third grade and in the fourth grade this changes due to more difficult curriculum and pre-puberty phase. The lack of enthusiasm for the language can be seen. The teachers list some of the most interesting activities that students like in English: TPR (Total Physical Response) activities, songs, card games and contests. They are very successful in remembering new words and acting, and they are weaker when it comes to writing words and sentences, learning certain expressions and pronunciation. The English teachers use the mother tongue in their class when they need to clear something out to students, especially to weaker students. Moreover, they use it when they can correlate Croatian and English language contents, when they need to discipline students and when they explain homework and certain new tasks. Teachers use around $70 \%$ of the mother tongue in the first grade in English, and that percentage decreases by years. Moreover, teachers like to correlate English and Croatian when students already know something in Croatian and then they can upgrade it in the English class. Croatian and English curricula are not harmonized enough; that is why sometimes it is difficult to correlate the subjects and the teaching content. When it comes to using technology, teachers say that they use auditive materials only.

The school headmaster in the interview says that it is important to learn the foreign language from the first grade, the earlier the better. In the school, days connected with languages are celebrated, such as 21 st February, which is The Mother Tongue Day. Every year, they also celebrate The School Day when students are encouraged to think about the mother tongue and the foreign language. Students did not have the opportunity to communicate with students from other countries, but the school via E-twinning cooperates with schools in other parts of Europe. There is the lack of school equipment.

Conversation with focus groups was conducted in each grade. In the first grade ten students participated, in the second grade nine students, in the third grade eleven students and in the fourth grade eight students. The conversation with students confirmed the survey results, their activity preferences and the level of learning complexity in Croatian and English.

\section{Discussion}

Grade analysis results show that school success in Croatian and English is very good, but through years of schooling that success slowly decreases. This is especially emphasized in the fourth grade, where the fall in success is the most obvious. Teachers attribute that to the development phase that children are in. Moreover, they say it is due to more difficult curriculum in the fourth grade. The survey shows that students are highly motivated for different activities in the class. There is the slight difference in English and Croatian. Students rank reading very high, both in English and Croatian. Listening and speaking are in the middle position. Conversation is better ranked in the English than in the Croatian class. The main difference is that students like to write more in the Croatian class than in the English class. According to the results, this is probably due to the difficulty in writing English words. An interesting fact is that learning the foreign language takes a lot more place in the human brain due to more neuron connections involved in processing information. This is why it is more difficult for students to do tasks in English than in Croatian, like writing. Moreover, students like learning Croatian and English very much (Figures 4 and 5) and they do not think they are hard to learn (Figures 6 and 7). Students say that Croatian helps them to better understand the foreign language and they find it useful when the English teacher speaks sometimes in the mother tongue. Bates and Whiney [10] in their competition model also advocate that the mother tongue have a significant influence in learning the foreign language because students often try to find language equivalents in their mother tongue and confide in the language rules of the mother tongue. So, before learning the foreign language they have the language awareness developed that helps them draw parallels between languages and see the differences. The student survey also shows that students in English class like games, singing and learning new words the most. Similar results are found in ELLiE research. Enever also mentions these activities as the most interesting ones to young learners of the foreign language (Enever, 2011, 35) [11].

Most of hypotheses of the research are confirmed: Croatian and English parallel learning in lower grades does not decrease language acquiring, but enhances it and encourages language development processes because the bilingual brain receives more information and makes a complex network of information that support one another. This is visible in the grade analysis which confirms very good success in both languages. The intercultural aspect in this hypothesis can be examined more thoroughly. Learning about the new culture and its language broadens students' horizons and gives them the opportunity to communicate with people from around the world. This is especially important because English is considered to be the world language, the third most common language that is spoken in the world. By learning English, students learn about different parts of the world: America, the United Kingdom, Australia and other parts of the world where English is the mother tongue. They meet different dialects and cultural diversity, which they can correlate with dialects and diversity in Croatia. So, it is important to enable students to hear different accents in English in order to introduce them with the language diversity and richness. Chomsky described symbolically the need of the language exposure in early age as 'the rich linguistic bath' (Chomsky, 1987, 55). Therefore, 
if a child often hears the language, and its different dialects, it will be more efficient in the target language. This intercultural dimension is an important part of the Civic education in schools. Therefore, the foreign language knowledge and skills are essential in business, economy, travelling and life in general. The notion that learning one language enhances learning another language is a key to improving teaching methods and strategies. But very aspects of the languages need to be considered. Croatian and English, though at different linguistic branches, share similarities. This notion, if implemented well in the lesson, can enhance the teaching foreign language process.

Further on, the second hypothesis cannot be entirely confirmed because according to students' grades, students are more successful in English in the first, the second and the third grade, but in the fourth grade that changes and the significant fall in the success in English is recorded. Teachers who were interviewed explain that this is due to the complexity of Croatian language and teaching areas in Croatian class. The important thing to consider is also the number of lessons per week in each subject. While Croatian is held every day, English is held only twice a week, so there is a disbalance between the complexity of the teaching content and teaching hours in these two subjects.

The third hypothesis can also be partly confirmed because students expressed in the survey that they are highly motivated and positively oriented towards language learning, and this can indicate a greater success in language learning. However, there are more factors that influence language learning, and this is one of them. So, to examine stronger correlation between these factors and school success, the further research needs to be conducted. But this is a good start and indication for further studies.

\section{Conclusions}

Early language learning is very important in the modern world of technologies, so it is crucial to emphasize the importance of multilingual competence which will help students in their future careers and life. Moreover, it is important to teach students to their mother tongue and cherish it as the part of their identity. Teachers have a major role in conveying these important notions about languages.

Positive students' attitudes towards language learning in lower grades in the primary school are recorded, as well as their very good success. This shows that learning foreign languages from the early age is very effective and encourages students' cognition processes. What is more, it is important to correlate languages not just because of the language knowledge, but because the intercultural education.
Languages are like communicative human media, they connect people, tell about cultures and folklore, they act as mediators between people and if one knows the language well, the message will be conveyed well. The research implies this importance and encourages teachers to constantly improve their work and keep their minds open when it comes to the language learning.

\section{Acknowledgements}

Special thanks to professor Klara Bilić Meštrić from the Centre for Croatian Studies, University in Zagreb for providing suggestions and useful comments during the creation of the manuscript.

\section{REFERENCES}

[1] D., Pavličević Franić. Institutional learning/acquiring Croatian in the system of multilingual discourse, A child and the language today: A child and multilingualism, Faculty of Educational Sciences in Osijek, 19-26, 2006.

[2] G. B., Brown. Principles of Language Learning: Theories of second language acquisition, Longman, USA, San Francisco, 2000 .

[3] J., Mihaljević Djigunović. Interaction between the mother tongue and the foreign language in language understanding and production, A child and the language today: A child and the text, Faculty of Educational Sciences in Osijek, 267-285, 2011.

[4] R., Matasović. Introduction to comparative linguistics, Matica hrvatska, Croatia, 2001.

[5] N., Chomsky. Consensus and controversy, Falmer Press, UK, 1987.

[6] Croatian Ministry of Science, Education and Sport. Teaching plan and program, Ministry of Science, Education and Sport, Croatia, 2006.

[7] J., Enever. Early Language Learning in Europe, British Council, UK, 2011.

[8] Jelaska et al. Croatian as the second and the foreign language, Croatian university publishing, Croatia, 25-39, 2005.

[9] G. Milas. Research methods in psychology and other social sciences, Naklada Slap, Croatia, 2009.

[10] E., Bates. Comprehension and production in early language development, Singular Publishing Group, USA, 1993.

[11] J., Enever. Early Language Learning in Europe, British Council, UK, 2011. 